
\title{
3 Research Square \\ Wildfire Alters the Linkage Between Total and Available Soil C:N:P Ratios and the Stoichiometric Effects on Fine Root Growth in a Chinese Boreal Larch Forest
}

\author{
Jianjian Kong \\ Shenyang Normal University https://orcid.org/0000-0003-3709-9975 \\ Xing jia Xiang \\ Anhui University \\ Jian Yang ( $\nabla$ jian.yang@uky.edu ) \\ University of Kentucky https://orcid.org/0000-0002-2170-589X
}

\section{Research Article}

Keywords: Disturbance, Fire, Soil nutrients, Ecological stoichiometry, Fine root

Posted Date: July 7th, 2021

DOI: https://doi.org/10.21203/rs.3.rs-615061/v1

License: (c) (1) This work is licensed under a Creative Commons Attribution 4.0 International License.

Read Full License

Version of Record: A version of this preprint was published at Plant and Soil on November 10th, 2021. See the published version at https://doi.org/10.1007/s11104-021-05215-1. 


\section{Abstract}

\section{Background and aims}

Wildfire is a primary driver of ecosystem functioning, and the fire-induced changes in the cycling and balance of multiple nutrients may influence the response of plant growth to burning. However, the relationships between total and available soil stoichiometry and stoichiometric effects on the growth of fine roots following fire in forests remain unclear.

\section{Methods}

We measured the total and available soil $\mathrm{C}, \mathrm{N}$ and $\mathrm{P}$ concentrations, their ratios and fine root biomass (FRB) at an unburned control, 1-year-postfire and 11-year-postfire sites in a Chinese boreal larch forest. The relationships between soil stoichiometry and FRB were analyzed.

\section{Results}

Wildfire significantly reduced the total and available soil C:N:P ratios and FRB immediately postfire. Eleven years postfire, most indicators recovered to the pre-fire levels except total soil C:P and N:P ratios, and available $\mathrm{C}: \mathrm{N}$ ratio. Wildfire immediately increased the correlations between total and available soil $\mathrm{C}: \mathrm{N}: \mathrm{P}$ ratios, as well as between FRB and soil $\mathrm{C}: \mathrm{N}: \mathrm{P}$ ratios, but reduced the correlations between FRB and soil nutrient supply. These effects became weaker over time.

\section{Conclusions}

The effects of wildfire on biogeochemical processes in boreal ecosystems extend to the relationships between total and available soil stoichiometry. Wildfire strengthens the linkage between fine roots and soil stoichiometry, but weakens the effects of soil nutrient supply in the Great Xing'an Mountains. Therefore, the effects of wildfire on the coupling of soil $\mathrm{C}, \mathrm{N}$ and $\mathrm{P}$ cycling can produce a more complex soil-plant interaction in the postfire early succession stage of boreal larch forest.

\section{Introduction}

Wildfire is a dominant natural disturbance in boreal forests, annually burning $1 \%$ of the boreal forest area (Stocks et al. 1998) and influencing the elemental cycling and balance within the forest ecosystems (Bond-Lamberty et al. 2007; Cavard et al. 2019), which may further affect the responses of forest regrowth and production to wildfire (Alexander et al. 2018). Wildfires can volatilize soil carbon (C) and release large numerous of inorganic nutrients to the soil through consuming forest floor (Adkins et al. 2019; Kishchuk et al. 2016), which promotes the recycling of C, nitrogen $(N)$ and phosphorus $(P)$ bound in the organic matter. Meanwhile, wildfires release lots of available $\mathrm{N}$ and $\mathrm{P}$ from the burned litter (Certini 2005; Smithwick et al. 2005; Turner et al. 2007), which has the potential to stimulate the growth of regeneration plants in the most N-limited boreal forests (Liu and Yang 2014; Romme et al. 2009). Compared to the effects of wildfire on individual element $\mathrm{C}, \mathrm{N}$, and $\mathrm{P}$ cycling in the soil, its effect on their 
stoichiometric relationship, may be just as important as the changes in the absolute contents of $\mathrm{C}, \mathrm{N}$ and $P$ because soil C:N:P stoichiometry can influence central ecosystem functioning such as optimal plant growth and biogeochemical processes (Creamer et al. 2014; Ren et al. 2016; Sophie et al. 2015).

The few prior studies have reported that total soil C:N:P stoichiometry increased following fire and then decreased with postfire stand age in a boreal forest (Hume et al. 2016) and that recent burning decreased soil labile C:P and N:P ratios (Butler et al. 2017), but increased total soil C:P and N:P ratios in tropical forest ecosystems (Butler et al. 2020). These studies, however, usually focused on the concentrations and stoichiometry of plant-available and total pools of element $\mathrm{C}, \mathrm{N}$ and $\mathrm{P}$ and failed to investigate the wildfire effects on the linkage between total and available soil nutrient pools even though their interactions greatly affect biogeochemical cycling (Baret et al. 2015; Cavard et al. 2019). For instance, the increased available soil $\mathrm{N}$ and $\mathrm{P}$ concentrations can stimulate microbial activity and subsequent mineralization of soil organic matter (Caldwell et al.), and thus affect the total soil C:N:P stoichiometry (Shen et al. 2018). A recent research showed that mineralization of SOM increased with available soil C:N and $\mathrm{C}: P$ ratios because available soil stoichiometry could shift microbial community composition by increasing organic matter mineralization to maintain the microbial stoichiometric homeostasis (Wei et al. 2020). Likewise, total soil C:N:P stoichiometry can regulate soil $C, N$, and $P$ biogeochemical processes through directly affecting the genetic resistance of microbial groups which involved in $\mathrm{C}, \mathrm{N}$, and $\mathrm{P}$ cycling (Luo et al. 2020), and thus likely affect the supply of available soil $\mathrm{N}$ and P. Therefore, to fully appreciate the effects of wildfire on biogeochemical processes, it is also vital to consider the relationships between total and available soil stoichiometry, which may provide new insight into fire-induced ecological consequences.

Furthermore, fire-induced stoichiometric shifts in the balance of element $\mathrm{C}, \mathrm{N}$, and $\mathrm{P}$ in soils have the potential to influence soil biotic processes (Butler et al. 2019; Toberman et al. 2014), plant nutritional status and forest productivity. Some studies have reported that prescribed-fire could alter foliar $\mathrm{N}$ and $\mathrm{P}$ concentrations and N:P ratio through its effects on the amounts and balance of available soil nutrients in subtropical flatwoods (Schafer and Mack 2014) and tropical forest ecosystems (Butler et al. 2016). In contrast, the meta-analysis study showed that fire effects on plant N:P ratio were not related to the changes in available soil nutrients (Dijkstra and Adams 2015). However, these studies generally concentrated on the effects of soil nutrients status on aboveground plant tissues (i.e., leaf) and neglected the effects on belowground roots, particularly fine roots. In fact, fine roots (i.e., roots $<2 \mathrm{~mm}$ in diameter) are very important for $\mathrm{C}$ flow and biogeochemical cycling of terrestrial ecosystem (Matamala et al. 2003; Yuan and Chen 2010). For instance, fine roots are the primary organ for plants to absorb water and nutrients from the soil and serve as a major channel of $C$ below ground (Kyaschenko et al. 2019). Fine root mortality and decomposition can release large nutrients to the soil due to fast turnover rates (Gill and Jackson 2000). Previous studies have shown that the amount of $C$ and nutrients cycling to the soil from fine roots may equal or exceed those from above-ground litter (Norby, Fitter \& Jackson 2000) although fine root biomass contributes only a small part of total forest biomass (Vogt et al. 1996). However, despite the close linkage between fine roots and soil environments, the response of fine root growth to fire-induced stoichiometric shifts in soils remains unclear. Hence, a better understanding of how fire- 
induced stoichiometric shifts in soil influence fine root growth could help us fully unravel the fire's ecological effects.

In this study, we examined the wildfire effects on total and available soil $\mathrm{C}, \mathrm{N}$, and $\mathrm{P}$ concentrations and stoichiometry among three study sites (control, 1-year-postfire, and 11-year-postfire) in the Great Xing'an Mountains in China and determined the fire-induced changes in soil stoichiometry on fine root biomass (FRB). The Great Xing'an Mountains are at the extreme southern boundary of the Eurasian boreal forests, and more than $70 \%$ of the forested area is occupied by Dahurian larch (Larix gmelinii Rupr.) (Xu 1998). Wildfire is the primary natural disturbance in these forests, and regulates the ecosystem structure and function (Cai et al. 2013). Recently, several studies have evaluated the effects of wildfire on forest productivity (Liu and Yang 2014), soil physicochemical and biological properties (Kong et al. 2015; Kong et al. 2019; Xiang et al. 2015) and available soil nutrient composition (Kong et al. 2018); however, information about the relationships between total and available soil stoichiometry and stoichiometric effects on the growth of fine roots following fire are unclear. Specially, we will focus on: (1) the dynamics of available and total soil $\mathrm{C}, \mathrm{N}$ and $\mathrm{P}$ concentrations and their stoichiometry change along a temporal gradient of fire history; (2) the relationships between total and available soil C:N:P stoichiometry; and (3) the response of fine root growth to the fire-induced changes in soil C:N:P stoichiometry and nutrient supply. We expected that wildfire would decrease soil C:N:P ratios due to more loss of $C$ to the atmosphere and more release of $\mathrm{N}$ and $\mathrm{P}$ to the soil through burning fuels. Moreover, we also expected that the relationships between total and available soil C:N:P stoichiometry would be more closer due to the fire-driven recycling of soil $\mathrm{C}, \mathrm{N}$ and $\mathrm{P}$ and then would become weaker over time. Finally, given wildfire would shift soil C:N:P stoichiometry, we expected that the fine root growth would be more responsive to the soil C:N:P stoichiometry compared to the individual changes in soil nutrient element immediately after the fire.

\section{Materials And Methods}

\section{Study site and sampling}

The study area is located at the Huzhong National Natural Reserve (approximately 167, $213 \mathrm{ha}$ ) of the Great Xing'an Mountains in northeastern China $\left(51^{\circ} 17^{\prime} 42^{\prime \prime} \mathrm{N}, 122^{\circ} 42^{\prime} 14^{\prime \prime} \mathrm{E}\right.$ to $\left.51^{\circ} 56^{\prime} 31^{\prime \prime} \mathrm{N}, 123^{\circ} 18^{\prime} 05^{\prime \prime} \mathrm{E}\right)$. The area has a terrestrial monsoon climate with a long and severe winter. The mean annual temperature is $-4.7^{\circ} \mathrm{C}$ and the mean annual average precipitation is $495 \mathrm{~mm}$. The soils of the region have been classified as brown coniferous forest soils in the Chinese soil taxonomy. The dominant overstory tree species are Dahurian larch (Larix gmelinii), white birch (Betula platyphylla) and aspen (Populus davidiana). The Great Xing'an Mountains are usually affected by frequent forest fires. From 1990 to 2010, a total of 167 forest fires occurred, each burning area of more than 200 ha in this region (Liu et al. 2012). Most fires mainly occurred in late spring and early summer. In the Huzhong Natural Reserve, two wildfires caused by extreme weather conditions started on June 7th, 2000, and June 26th, 2010, and burned about 8700 and 700 ha, respectively. 
To examine the postfire changes in soil nutrient status and the effects of such changes on fine root growth along a temporal fire history gradient, we selected sample plots based on fire history. This study had one unburned control and two fire history levels (i.e., 1-year-postfire and 11-year-postfire). An adjacent unburned area with similar pre-fire vegetation, topography and soil properties as those of the two burned areas was selected as a control (Table 1). Unburned area is a mature larch forest without being affected by wildfires in nearly 80 years according to records of the management committee of Huzhong National Natural Reserve. We collected a total of 60 soil samples (12 control samples, 24 1-year-postfire samples and 24 11-year-postfire samples) from the end of July to the middle of August in 2011. Within each of the 60 plots $(40 \mathrm{~m} \times 40 \mathrm{~m}$ ), we collected soils from 5 points (4 vertices and the center) at the surface mineral soil depths of $0-15 \mathrm{~cm}$. For each plot, the samples from the five points were mixed into one composite sample, resulting in a total of 60 composite samples. All samples were placed in a cooler with ice bags and then transported to the laboratory.

Table 1

Basic characteristics of three study sites.

\begin{tabular}{|c|c|c|c|}
\hline & Control & 1-year-post-fire & 11-year-post-fire \\
\hline Location & $\begin{array}{l}122^{\circ} 57^{\prime} \mathrm{N}, 51^{\circ} 51^{\prime} \\
\mathrm{E}\end{array}$ & $122^{\circ} 55^{\prime} \mathrm{N}, 51^{\circ} 52^{\prime} \mathrm{E}$ & $122^{\circ} 49^{\prime} \mathrm{N}, 51^{\circ} 51^{\prime} \mathrm{E}$ \\
\hline $\begin{array}{l}\text { Elevation } \\
(\mathrm{m})\end{array}$ & $817-1061$ & 864-1095 & $901-1078$ \\
\hline $\begin{array}{l}\text { Slope } \\
\text { (degree) }\end{array}$ & $0-37$ & $1-30$ & $0-30$ \\
\hline Aspect & North / south & North / south & North / south \\
\hline $\begin{array}{l}\text { vegetation } \\
\text { type }\end{array}$ & $\begin{array}{l}\text { Dahurican larch } \\
\text { (L.gmelinii) }\end{array}$ & $\begin{array}{l}\text { Dahurican larch (L. gmelinii) } \\
\text { (pre-fire vegetation) }\end{array}$ & $\begin{array}{l}\text { Dahurican larch (L. gmelinii) } \\
\text { (pre-fire vegetation) }\end{array}$ \\
\hline $\begin{array}{l}\text { Stand age } \\
\text { (year) }\end{array}$ & Stand age $\geq 110$ & Pre-fire stand age $\geq 110$ & Pre-fire stand age $\geq 110$ \\
\hline $\begin{array}{l}\text { Bedrock } \\
\text { type }\end{array}$ & $\begin{array}{l}\text { Granitoid and } \\
\text { quartzite }\end{array}$ & Granitoid and quartzite & Granitoid and quartzite \\
\hline Soil type & $\begin{array}{l}\text { Brown coniferous } \\
\text { forest soil }\end{array}$ & Brown coniferous forest soil & Brown coniferous forest soil \\
\hline Fire type & & Stand-replacing fire & Stand-replacing fire \\
\hline Fire year & & 2010 & 2000 \\
\hline $\begin{array}{l}\text { Fire area } \\
\text { (ha) }\end{array}$ & & 700 & 8700 \\
\hline
\end{tabular}

Soil nutrient supply and fine root sampling 
The soil nutrient supply was measured using the Plant Root Simulator probes (PRS®, Western Ag Innovations, Saskatoon, SK, Canada) via in situ incubation. The PRS ${ }^{\circledR}$ probes can absorb ions from soil like plant uptake for nutrients. As a convenient and economical soil analysis tool, the PRS ${ }^{\circledR}$ technology has been widely applied in agronomic, forestry, and ecological research. Each pair of the probes consists of cation and anion exchange resin membranes, which concurrently adsorb cations (e.g., $\mathrm{NH}_{4}^{+}$) and anions (e.g., $\mathrm{NO}_{3}{ }^{-}, \mathrm{PO}_{4}{ }^{3-}$ ). The cation probes are saturated with $\mathrm{Na}^{+}$and the anion probes are saturated with $\mathrm{HCO}_{3}{ }^{-}$. Values are $\mu \mathrm{g}$ element $10-\mathrm{cm}^{-2}$ per $15-\mathrm{cm}$ depth.

In each plot, we randomly selected two of five soil sampling points as in situ measurement locations (Fig. 1). At each in situ location, we buried a sharpened open PVC (polyvinyl chloride plastic) tube (10-cm diameter, 20-cm long) into the soil (20-cm depth) as an external root exclusion cylinder (Fig. 1). Then, we vertically inserted one pair of PRS $®$ probes in each PVC tube. The 60 pairs of probes were kept for three weeks in situ locations during the growing season. Then, all probes were removed, washed immediately with distilled water, and placed in zipseal plastic bags. Lastly, all probes were shipped to Western Ag Innovations, Saskatoon, SK, Canada on ice for analysis; the two pairs of probes from the same plot were pooled for elution and analysis.

Fine roots were sampled using the soil-coring method (inside diameter 10-cm PVC tube). In this study, the probe pair and soil core were incubated together in the same PVC tube. After the incubation, one pair of probes was removed, then the PVC tubes were pulled out by carefully digging the soil and finally root sample was collected from each tube. The fine root samples from the same plot were mixed as one sample. On the same day, we carefully washed the roots in the water to eliminate the adherent soil. The living fine roots ( $<2 \mathrm{~mm}$ in diameter) were separated by hand from the samples and the dead roots were discarded. The sorting of dead and living roots was based on root color, where living roots are white and dead roots are dark (Brassard et al. 2011). Then, the root samples were oven-dried at $70^{\circ} \mathrm{C}$ for $48 \mathrm{~h}$ and weighed them.

\section{Lab methods}

The soil samples were screened over a 2-mm sieve and then divided into two parts: one part was stored at $4^{\circ} \mathrm{C}$ for the extractable $\mathrm{N}$ and soil dissolved organic carbon (DOC) analysis; the other was air-dried and then finely ground for the analysis of total soil carbon (TC), phosphorus (TP), nitrogen (TN) and available phosphorus (AP). Soil TP was determined using the perchloric/sulfuric acid digestion method and the Mo-Sb anti-spectrophotography method (Lu, 2000). Soil TC and TN were determined by dichromate oxidation and titration with ferrous ammonium sulfate (Walkley and Black 1934). The concentrations were measured as \% and were used to calculate the stoichiometric ratios. Soil DOC was determined by a Liqui TOC analyser (Elementar Liqui TOC, Elementar Co., Hanau, Germany). We used soil extractable inorganic $\mathrm{N}$ (i.e. $\mathrm{NH}_{4}{ }^{+}$and $\mathrm{NO}_{3}{ }^{-}$) and $\mathrm{P}$ concentrations as the indicator of available soil $\mathrm{N}(\mathrm{AN})$ and $\mathrm{P}$. To measure soil extractable inorganic $\mathrm{N}$ (including $\mathrm{NH}_{4}{ }^{+}$and $\mathrm{NO}_{3}{ }^{-}$), a 10 -g fresh soil sample was extracted in $40 \mathrm{~mL}$ of $2 \mathrm{M} \mathrm{KCl}$ by shaking the sample for $1 \mathrm{~h}$ at $160 \mathrm{r} / \mathrm{min}$. extracts were filtered with Whatman No.1 filter paper pre-leached with $2 \mathrm{M} \mathrm{KCl}$ and deionised water. The resulting extracts were kept frozen until 
analyzed. Ammonium and nitrate concentrations were measured using a Continuum Flow Auto Analyzer 3 (Bran + Luebbe, Norderstedt, Germany) (Carter and Gregorich 2008). Soil AP was extracted by shaking soil for 30 min with $0.1 \mathrm{M} \mathrm{NaHCO}_{3}(1: 20 \mathrm{w}: \mathrm{v})$, and $\mathrm{PO}_{4}{ }^{3-}$ was measured by the molybdenum blue method.

\section{Calculations and statistical analysis}

On a mass basis, we calculated total soil C:N:P ratios using TC, TN and TP concentrations, as well as got available soil C:N:P ratios using DOC, AN and AP concentrations. We checked the data for normality and homogeneity of variance. One-way ANOVA was used to determine how wildfire affected the soil $\mathrm{C}, \mathrm{N}$ and $P$ concentrations and their stoichiometry, and fine root biomass (FRB). A Games-Howell post hoc test was used to identify differences in the soil C, N and P concentrations, C:N:P ratios and FRB among the control, 1-year-postfire and 11-year-postfire sites. Spearman rank-order correlation analysis was used to identify the correlations between total and available soil $\mathrm{C}, \mathrm{N}$ and $\mathrm{P}$ concentrations. The relationships between total and available soil C:N:P stoichiometry, and between FRB and soil C:N:P stoichiometry and the supplies of soil $\mathrm{N}$ and $\mathrm{P}$ for each study site were reflected through simple linear regression analysis. In this study, all statistical analyses were conducted with the R statistical package (version 3.2.4; R Core Team 2016), and the significance level was $a<0.05$.

\section{Results}

\section{The effects of wildfire on soil $\mathrm{C}, \mathrm{N}$, and $\mathrm{P}$ concentrations and their stoichiometric ratios}

Wildfire had different effects on the soil C, N and P concentrations (Table 2). Compared to the control, wildfires showed little effects on the soil TC and TN concentrations at either the 1-year-postfire or the 11year-postfire sites. Soil TP concentration was $82 \%$ and $50 \%$ higher than the control at the 1-year-postfire and 11-year-postfire sites, respectively. Soil DOC concentration was $34 \%$ and $22 \%$ lower than the control at the 1-year-postfire and 11-year-postfire sites, respectively. However, wildfire significantly increased soil AN and AP concentrations by $59 \%$ and $26 \%$, respectively, at the 1-year-postfire site, and these two indicators recovered to the control levels at the 11-year-postfire site. 
Table 2

Total and available soil $\mathrm{C}, \mathrm{N}$, and $\mathrm{P}$ concentrations, and their ratios at the control ( $\mathrm{n}=12$ plots), 1 -yearpost-fire (1-YPF, $n=24$ plots), and 11-year-post-fire (11-YPF, $n=24$ plots) sites.

\begin{tabular}{|c|c|c|c|c|c|c|}
\hline Soil total & $\mathrm{TC}(\%)$ & TN (\%) & $\operatorname{TP}(\%)$ & C:N & C:P & $N: P$ \\
\hline Control & $8.14 \pm 0.79 a$ & $\begin{array}{l}0.37 \pm \\
0.03 a\end{array}$ & $\begin{array}{l}0.05 \pm \\
0.005 b\end{array}$ & $\begin{array}{l}21.84 \pm \\
1.01 a\end{array}$ & $\begin{array}{l}175.5 \pm \\
17.1 \mathrm{a}\end{array}$ & $\begin{array}{l}8.21 \pm \\
0.86 a\end{array}$ \\
\hline 1-YPF & $6.32 \pm 0.43 a$ & $\begin{array}{l}0.33 \pm \\
0.02 \mathrm{a}\end{array}$ & $\begin{array}{l}0.09 \pm \\
0.006 a\end{array}$ & $\begin{array}{l}18.30 \pm \\
0.66 \mathrm{c}\end{array}$ & $75.2 \pm 6.4 c$ & $\begin{array}{l}3.96 \pm \\
0.27 c\end{array}$ \\
\hline 11-YPF & $7.96 \pm 0.65 a$ & $\begin{array}{l}0.38 \pm \\
0.03 a\end{array}$ & $\begin{array}{l}0.07 \pm \\
0.004 a\end{array}$ & $\begin{array}{l}20.96 \pm \\
0.69 a b\end{array}$ & $\begin{array}{l}113.5 \pm \\
10.7 b\end{array}$ & $\begin{array}{l}5.36 \pm \\
0.47 \mathrm{~b}\end{array}$ \\
\hline $\begin{array}{l}\text { Soil } \\
\text { available }\end{array}$ & $\begin{array}{l}\mathrm{DOC}(\mathrm{mg} \\
\left.\mathrm{kg}^{-1}\right)\end{array}$ & $\begin{array}{l}\text { AN (mg } \\
\left.\mathrm{kg}^{-1}\right)\end{array}$ & $\begin{array}{l}\text { AP }(m g \\
\left.k g^{-1}\right)\end{array}$ & C:N & C:P & $N: P$ \\
\hline Control & $\begin{array}{l}473.2 \pm \\
15.4 a\end{array}$ & $\begin{array}{l}32.15 \pm \\
1.76 b\end{array}$ & $\begin{array}{l}22.46 \pm \\
1.63 b\end{array}$ & $\begin{array}{l}15.35 \pm \\
1.12 a\end{array}$ & $\begin{array}{l}23.21 \pm \\
2.81 \mathrm{a}\end{array}$ & $\begin{array}{l}1.54 \pm \\
0.16 \mathrm{a}\end{array}$ \\
\hline 1-YPF & $\begin{array}{l}310.0 \pm \\
21.1 b\end{array}$ & $\begin{array}{l}51.12 \pm \\
3.06 a\end{array}$ & $\begin{array}{l}28.40 \pm \\
1.70 a\end{array}$ & $6.23 \pm 0.67 c$ & $\begin{array}{l}11.74 \pm \\
1.15 b\end{array}$ & $\begin{array}{l}1.96 \pm \\
0.15 a\end{array}$ \\
\hline 11-YPF & $\begin{array}{l}370.7 \pm \\
19.4 \mathrm{~b}\end{array}$ & $\begin{array}{l}34.00 \pm \\
1.27 b\end{array}$ & $\begin{array}{l}21.25 \pm \\
1.57 b\end{array}$ & $\begin{array}{l}10.70 \pm \\
0.68 b\end{array}$ & $\begin{array}{l}19.82 \pm \\
2.16 \mathrm{a}\end{array}$ & $\begin{array}{l}1.77 \pm \\
0.21 \mathrm{a}\end{array}$ \\
\hline \multicolumn{7}{|c|}{$\begin{array}{l}\text { Values in the Table } 2 \text { are means } \pm \text { standard error (s.e.); different letters between three sites in a row } \\
\text { indicate significant difference between two sites at } 0.05 \text { levels }(p<0.05 \text {, one-way ANOVA or Post ho } \\
\text { Games-Howell test). TC: total soil carbon; TN: total soil nitrogen; TP: total soil phosphorus; DOC: soi } \\
\text { dissolved organic carbon; AN: soil extractable nitrogen; AP: soil extractable phosphorus. }\end{array}$} \\
\hline
\end{tabular}

Wildfire had numerous significant effects on the soil C:N:P stoichiometry at the two burned sites relative to the control (Table 2). At the 1-year-postfire site, wildfire greatly reduced the total soil C:N, N:P and C:P ratios, by $14 \%, 57 \%$ and $49 \%$, respectively. Eleven years postfire, total soil C:N ratio recovered to pre-fire control level. In addition, total soil N:P and C:P ratios increased over time, but were still significantly lower at the 11-year-postfire site than those at the control site. Similarly, at the 1-year-postfire site, available soil C:N and C:P ratios were $60 \%$ and $50 \%$ lower than the control, respectively. At the 11-year-postfire site, available soil $\mathrm{C}: \mathrm{N}$ ratio was still significantly lower than the control, whereas available soil $\mathrm{C}: \mathrm{P}$ ratio recovered to the control level. Additionally, wildfire showed little effect on the available soil N:P ratio at the two burned sites.

\section{Relationships between total and available soil C:N:P stoichiometry}

Wildfire significantly affected the correlations between available and total soil nutrient pools (Fig. 2). The soil TC and TN concentrations were significantly correlated positively between each other at the two burned and control sites. Soil TC was correlated negatively with DOC concentration at the control site, and positively related to AN concentration at the 11-year-postfire site. There was no significant correlations between soil TC and TP and DOC concentrations at the control and 1-year-postfire site. 
Comparatively, soil TN concentration was not related to available and total soil $\mathrm{C}$ and $\mathrm{P}$ concentrations at the two burned and control sites, but positively correlated with soil AN concentration only at the 11-yearpostfire site. Soil TP concentration was strongly correlated with soil AP and DOC concentrations at the 1year-postfire site, but was not correlated with other soil indicators at the control and 11-year-postfire sites. Soil AP concentration was significantly correlated negatively with soil DOC concentration at the control site.

Wildfire greatly altered the relationships between total and available soil C:N:P ratios (Fig. 3). At the control site, total soil C: $\mathrm{N}$ ratio was marginally correlated negatively with the available soil C: $\mathrm{N}$ ratio $(\mathrm{n}=$ $12, R^{2}=0.317, p=0.056$; Fig. $3 \mathrm{~A}$ ) and significantly correlated positively with the available C: $\mathrm{N}$ ratio at the 1-year-postfire (Fig. 3D) and 11-year-postfire sites (Fig. 3G). Total soil C:P ratio was not correlated with the available soil C:P ratio at the control site (Fig. 3B), but significantly correlated positively with the available soil C:P ratio at the 1-year-postfire site (Fig. 3E). Eleven years postfire, the relationships between total and available soil C:P ratios recovered to the control levels (Fig. $3 \mathrm{H})$. Similarly, the correlations between total and available soil N:P ratios were not significant at the control site (Fig. $3 \mathrm{C}$ ), but significantly positive at the 1-year-postfire site (Fig. 3F). However, there was no significant correlations between total and available soil N:P ratios at the 11-year-postfire site (Fig. 3I).

\section{Response of fine root biomass to the fire-induced changes in soil nutrient supply and C:N:P stoichiometry}

Wildfire greatly affected the soil nutrient supply (Fig. 4). At the 1-year-postfire site, soil N and P supplies were $210 \%$ and $157 \%$ higher than the control, respectively. Then, soil N and P supplies significantly declined to the control levels at the 11-year-postfire site. Fine root biomass (FRB) at the 1-year-postfire and 11 -year-postfire sites was $67 \%$ and $58 \%$ lower than the control, respectively (Fig. 5).

Wildfire affected the relationships between fine root growth and soil nutrient status (Fig. 6, 7). At the control site, FRB was significantly correlated positively with soil $\mathrm{N}$ supply but not correlated with soil $\mathrm{P}$ supply (Fig. 6). In contrast, FRB was not correlated with soil $\mathrm{N}$ and $\mathrm{P}$ supplies at the two burned sites (Fig. 6). Fine root growth showed different responses to the soil C:N:P stoichiometry at the control and burned sites (Fig. 7). At the control site, FRB was strongly correlated positively with the total soil C:N ratios (Fig. 7A), but not related to the total soil C:P and N:P ratios, and available C:N:P stoichiometry. At the 1-year-postfire site, FRB was significantly correlated positively with the total soil C:N:P stoichiometry, available $\mathrm{C}: \mathrm{N}$ and $\mathrm{C}: \mathrm{P}$ ratios (Fig. 7A-E). However, there were no significant correlations between FRB and available N:P ratio (Fig. 7F). At the 11-year-postfire site, FRB was significantly correlated negatively with the total soil C:N ratio (Fig. 7A). Comparatively, there were no significant correlations between FRB, total soil C:P and N:P ratios, and available C:N:P stoichiometry (Fig. 7B-F). Totally, the correlations between fine root growth and soil C:N:P stoichiometry were stronger at the 1-year-postfire site than those at the 11year-postfire and control sites. 


\section{Discussion}

\section{The effects of wildfire on soil $\mathrm{C}, \mathrm{N}$, and $\mathrm{P}$ concentrations and their stoichiometric ratios}

In this study, total soil $\mathrm{C}$ and $\mathrm{N}$ concentrations were not significantly different at the control and two burned sites (Table 2), because wildfire-induced $\mathrm{C}$ and $\mathrm{N}$ loss mainly focuses on vegetation, woody debris and $O$ horizon and little effects on the surface mineral soil (Johnson et al. 2007; Nave et al. 2011). Numerous studies have shown that fire had little effects on soil TC and TN contents (Adkins et al. 2019; Johnson et al. 2007; Wirth et al. 2002). However, soil TC loss was higher than soil TN loss immediately after the fire (Table 2), because a large portion of soil organic $\mathrm{N}$ survives following low intensity fire (Certini 2005). Thus such more decrease in soil TC than TN immediately following the fire resulted in the significant reduction in total soil C:N ratio (Table 2). Then total soil C:N ratio increased to the pre-fire level with time since fire due to inputs of $\mathrm{C}$ and $\mathrm{N}$ from the return of understory vegetation (e.g., herbaceous annual plants), litterfall and vegetation root turnover from the regenerating stands (Alexander et al. 2018; De Long et al. 2016; Yuan and Chen 2013), and biological fixation (Harden et al. 2003). However, in a boreal Jack pine forest of central Canada, Hume et al. (2016) reported that postfire total soil C:N ratio in the mineral layer exerted no significant changes with time since fire but that in the forest floor increased with the stand age because substantial litter was accumulated on the forest floor and provided organic matter for the soil.

In contrast to little changes in soil TC and TN after fire, soil TP concentration greatly increased at the 1year-postfire site (Table 2), suggesting that wildfires promote the $\mathrm{P}$ cycling by burning vegetation and forest floor, as found by Schaller et al. (2015). This confirms that previous work showing the mature or old boreal forests may not be able to keep a positive $\mathrm{P}$ balance because $\mathrm{P}$ is derived mainly from the geochemical weathering of bedrock and over time becomes increasingly bound in more stable forms by calcite minerals (Buendía et al. 2014; Huang et al. 2017; Walker et al. 1983). Such non-proportional changes in total soil $\mathrm{C}, \mathrm{N}$ and $\mathrm{P}$ resulted in significant reductions in the total soil C:P and N:P ratios immediately after fire (Table 2). Over time, total soil C:P and N:P ratios significantly increased but still were lower in the 11-year-postfire stand than the control, suggesting that long-term effects of wildfire on the balance of soil C, N and P cycling. Similarly, Hume et al. (2016) reported that the 15-year-postfire stand had lower total soil C:P and N:P ratios than the mature stands in the boreal forest of central Canada, and attributed the reductions to the increase in soil TP. In this study, soil TP concentration at the 11-year-postfire site was significantly lower than that in the 1-year-postfire site, suggesting substantial $P$ losses at the burned area. Several studies considered that the postfire P loss could be related to the surface runoff or erosion (Blake et al. 2010; Bodí et al. 2012) because most fire-increased $P$ accumulates in the surface soils (Certini 2005; Lagerström et al. 2009). Another possible explanation is that part of available $\mathrm{P}$ in soil could be utilized by regeneration plants and bound in plant tissues. These processes could be responsible for the $\mathrm{P}$ losses with time since fire in this study. Our results indicate that wildfire could not only greatly release $\mathrm{P}$ into the soil through burning plant biomass and forest floor but also lead 
to substantial P losses because the fire-caused removal of most the forest floor may be vulnerable to runoff or erosion (Pereira et al. 2016). Therefore, postfire engineering measures such as mulching forest residues may be needed to reduce and even stop soil erosion and ensure soil recovery (Fernández 2016).

Compared to the changes in total soil $\mathrm{C}, \mathrm{N}$, and $\mathrm{P}$ pools after fire, wildfires exerted greater effects on their available pools in the Great Xing'an Mountains, suggesting that available pools of soil $\mathrm{C}, \mathrm{N}$, and $\mathrm{P}$ were more responsive to wildfire that total pools. In fact, fire-produced ash with abundant available nutrients manly deposits on the surface soil and thus replenishs soil nutrients (Bodí et al. 2012). As a consequence, available soil $\mathrm{N}$ and $\mathrm{P}$ greatly increased immediately after fire (Table 2), but most $\mathrm{C}$ in biomass and litter could be volatized into atmosphere during burning except for pyrogenic carbon left on the surface soil (Kane et al. 2010). In this study, we found soil DOC in the 1-year-postfire site was significantly lower than that at the control site. Such non-proportional changes in available soil C, N, and $\mathrm{P}$ concentrations resulted in great reductions in available soil C:N and C:P ratios, which may promote microbial growth and activities, and thus increase mineralization of SOM (Wei et al. 2020). However, the change in available soil N:P ratio in the 1-year-postfire site was little relative to the control, which may be related to the concurrently substantial increases in AN and AP in the recently burned soils (Kong et al. 2018). This was not consistent with Butler et al. (2017) who found recent burned soils had significantly lower labile soil N:P ratio in Australian eucalypt forests. This discrepancy may be related to the differences in measurement method and ecosystem type. Butler et al. (2017) used water-hot-extractable $\mathrm{C}, \mathrm{N}$ and $\mathrm{P}$ as labile soil pools of these elements, whereas soil AN and AP in our study were extracted by 2 $\mathrm{M} \mathrm{KCL}$ and $0.1 \mathrm{M} \mathrm{NaHCO}_{3}$, respectively. Additionally, soils in Australian eucalypt forests are low-P and thus have high $\mathrm{N}: \mathrm{P}$ ratios in unburned areas, while burning increased labile soil $\mathrm{P}$ and decreased labile $\mathrm{N}$ resulting in lower soil labile N:P ratios (Butler et al. 2017). Eleven years postfire, available soil C:P ratio recovered to the prefire level, whereas available soil C:N ratio was still significantly lower than the control, suggesting that wildfire would exert a relatively long-term effect on available soil stoichiometry. The changes in available soil C:P and C:N ratios may be attributed to the slow recovery rate of soil DOC and large declines in AN and AP (Table 2). We found soil AN and AP decreased to the prefire levels Eleven years postfire, suggesting burned soils lost substantial $\mathrm{N}$ and $\mathrm{P}$ possibly because of leaching, erosion and plant uptake (Durán et al. 2008). Compared to the AN, AP losses was greater because biological fixation can replenish some available $\mathrm{N}$ for soil (De Long et al. 2016; DeLuca et al. 2008). These results indicates that wildfire could exert greater effects on available soil stoichiometry, which may produce profound effects mineralization of soil organic C (Shuman et al.) and plant growth.

\section{Relationships between total and available soil C:N:P stoichiometry}

In the three fire history site, the correlations between total and available soil C:N:P stoichiometry was the strongest at the 1-year-postfire site (Fig. 5), consistent with our expectation that wildfire could strengthen the relationship between available and total soil stoichiometry. This supports the idea that burning forest floor not only influences balances of soil $\mathrm{C}, \mathrm{N}$ and $\mathrm{P}$, but also their biogeochemical cycling due to the improvement of postfire soil environments (Adkins et al. 2019; Santín et al. 2016). At the 1-year-postfire 
site, there were lower available soil C:N:P ratios, suggesting a sufficient nutrient supply which could satisfy the microbial demand of optimum available $\mathrm{C}, \mathrm{N}$, and $\mathrm{P}$ ratios, and thus promote recovery of bacterial community (Wei et al. 2020). Our previous study in Great Xing'an Mountains has also shown that bacterial community structure could rapidly recover to the pre-fire levels because burned soils had higher $\mathrm{pH}$, AN and suitable moisture (Xiang et al. 2014), which may create beneficial conditions for SOC decomposition. And the bare surface soils at the 1-year-postfire site had lower total C:N:P ratios, indicating SOC may be vulnerable to microbial decomposition (Sistla and Schimel 2012). These processes can be responsible for the closer link between available and total soil C:N:P stoichiometry. As far as we know, this is the first study to show that the effects of wildfire on the relationships between total and available soil stoichiometry in boreal forest ecosystems. The novelty is critical for our in-depth understanding consequences of wildfire biogeochemical effects.

\section{Responses of fine roots growth to soil $\mathrm{N}$ and $\mathrm{P}$ supply and C:N:P stoichiometry following fire}

In this study, fine root biomass was significantly correlated positively with soil $\mathrm{N}$ supply at the control site but was not correlated with soil $\mathrm{N}$ and $\mathrm{P}$ supply at the two burned sites (Fig. 6). This was because a large amount of available $\mathrm{N}$ and $\mathrm{P}$ can be released into the soil through burning vegetation biomass and forest floor (Certini 2005). Another possible explanation was reduced plant uptake after fire because we observed almost all vegetation was killed by burning and regenerated vegetation was small in the two burned sites. Thus, fire fertilization effect can not only alleviate $\mathrm{N}$ limitation but also supply enough $\mathrm{N}$ and P for regeneration plant growth in the Great Xing'an Mountains. Dijkstra and Adams (2015) also found that fire had the potential to enhance or alleviate the magnitude of $\mathrm{N}$ and $\mathrm{P}$ limitation in plants.

Despite no significant correlations between FRB and soil nutrient supply after fire, FRB was significantly correlated positively with soil C:N:P stoichiometry at the recently burned site relative to the control and 11year-postfire sites, suggesting that FRB was more responsive to the fire-caused changes in soil resource stoichiometry than the increases in their absolute amounts. This supports the idea that soil C:N:P ratios can regulate plant growth and also indicate plant nutrient status (Fan et al. 2015; Zhang et al. 2019). Fire can release substantial available $\mathrm{N}$ and $\mathrm{P}$, which may not only potentially promote plant growth but also enable plants to optimize their tissue N:P ratio (Dijkstra and Adams 2015). In the fertile burned area, fine roots with optimal C:N:P ratios likely affect soil nutrient status because they can return nutrients to soils through the rapid turnover rate (Kyaschenko et al. 2019). Yuan and Chen (2010) have reported that fine roots contain $50.9 \mathrm{~kg} \mathrm{ha}^{-1}$ of $\mathrm{N}$ and $3.63 \mathrm{~kg} \mathrm{ha}^{-1}$ of $\mathrm{P}$, and their mortality contributes $18-58 \% \mathrm{TN}$ to forest soils. Therefore, these processes may lead to a stronger association between fine root growth and soil stoichiometry immediately after fire. Assuming that the interaction between fine roots and soil stoichiometry increases following fire in boreal forests, additional research should focus on the postfire relationships between the soil stoichiometry and fine root turnover and stoichiometry. 


\section{Conclusions}

Our study suggest that available pools of soil $\mathrm{C}, \mathrm{N}$ and $\mathrm{P}$ are more responsive to wildfire than total pools, and soil C:N:P stoichiometry is more sensitive to wildfire than individual elements in the boreal larch forest of the Great Xing'an Mountains. Additionally, wildfires can exert a relatively long-term effect on soil stoichiometry. Our results also suggest that wildfires strengthen the linkage between total and available soil C:N:P stoichiometry, as well as between FRB and soil C:N:P stoichiometry. Meanwhile, we found that fine root growth was controlled by soil $\mathrm{N}$ supply before fire in this forest ecosystem, whereas this effect was little following fire, suggesting that wildfire could alleviate $\mathrm{N}$ limitation by burning fuels. These findings indicate that wildfires can profoundly disrupt or even decouple the biogeochemical cycling of $\mathrm{C}$, $\mathrm{N}$ and $\mathrm{P}$ in the soil and produce a more complex soil-plant interaction in the postfire early succession stage of boreal larch forest. Future studies on the relationships between postfire soil stoichiometry and forest ecosystem structure and function are needed to improve the understanding of the soil-plant interaction in response to wildfire in boreal forest ecosystems.

\section{Declarations}

\section{Acknowledgments}

This research was supported by the National Key Research and Development Program of China (2017YFA0604403), the National Natural Science Foundation of China $(41501200,31800376$, 31800395), Natural Science Foundation from Science and Technology Department of Liaoning province (2019-ZD-0479).

\section{Conflict of interests}

The authors declare that they have no competing interests.

\section{References}

1. Adkins J, Sanderman J, Miesel J (2019) Soil carbon pools and fluxes vary across a burn severity gradient three years after wildfire in Sierra Nevada mixed-conifer forest. Geoderma 333: 10-22. doi: 10.1016/j.geoderma.2018.07.009.

2. Alexander HD, Natali SM, Loranty MM, Ludwig SM, Spektor VV, Davydov S, Zimov N, Trujillo I, Mack MC (2018) Impacts of increased soil burn severity on larch forest regeneration on permafrost soils of far northeastern Siberia. Forest Ecol Manag 417: 144-153. doi: 10.1016/j.foreco.2018.03.008.

3. Baret M, Pepin S, Ward C, Pothier D (2015) Long-term changes in belowground and aboveground resource allocation of boreal forest stands. Forest Ecol Manag 350: 62-69. doi:

10.1016/j.foreco.2015.04.019.

4. Blake WH, Theocharopoulos SP, Skoulikidis N, Clark P, Tountas P, Hartley R, Amaxidis Y (2010) Wildfire impacts on hillslope sediment and phosphorus yields. J Soils Sediments 10: 671-682. doi: 
10.1007/s11368-010-0201-y.

5. Bodí MB, Doerr SH, Cerdà A, Mataix-Solera J (2012) Hydrological effects of a layer of vegetation ash on underlying wettable and water repellent soil. Geoderma 191: 14-23. doi:

10.1016/j.geoderma.2012.01.006.

6. Bond-Lamberty B, Peckham SD, AhI DE, Gower ST (2007) Fire as the dominant driver of central Canadian boreal forest carbon balance. Nature 450: 89-92. doi: 10.1038/nature06272.

7. Brassard BW, Chen HYH, Bergeron Y, Paré D (2011) Differences in fine root productivity between mixed- and single-species stands. Funct Ecol 25: 238-246. doi: 10.1111/j.1365-2435.2010.01769.x.

8. Buendía C, Arens S, Hickler T, Higgins SI, Porada P, Kleidon A (2014) On the potential vegetation feedbacks that enhance phosphorus availability \&ndash, insights from a process-based model linking geological and ecological timescales. Biogeosciences 11: 3661-3683. doi: 10.5194/bg-113661-2014.

9. Butler OM, Elser JJ, Lewis T, Maunsell SC, Rezaei Rashti M, Chen C (2020) The multi-element stoichiometry of wet eucalypt forest is transformed by recent, frequent fire. Plant and Soil 447: 447461. doi: 10.1007/s11104-019-04397-z.

10. Butler OM, Lewis T, Chen C (2016) Prescribed fire alters foliar stoichiometry and nutrient resorption in the understorey of a subtropical eucalypt forest. Plant and Soil 410: 181-191. doi: 10.1007/s11104016-2995-x.

11. Butler OM, Lewis T, Chen C (2017) Fire alters soil labile stoichiometry and litter nutrients in Australian eucalypt forests. Int J Wildland Fire 26: 783-788.

12. Butler OM, Lewis T, Rashti MR, Maunsell SC, Elser JJ, Chen C (2019) The stoichiometric legacy of fire regime regulates the roles of micro-organisms and invertebrates in decomposition. Ecology 100: e02732.

13. Cai W, Yang J, Liu Z, Hu Y, Weisberg PJ (2013) Post-fire tree recruitment of a boreal larch forest in Northeast China. Forest Ecol Manag 307: 20-29. doi: 10.1016/j.foreco.2013.06.056.

14. Caldwell MM, Heldmaier G, Jackson RB, Lange OL, Mooney HA, Schulze E-D, Sommer U (2010) Permafrost Ecosystems Siberian Larch Forests Ecological Studies. Ecol Stud 209.

15. Carter MR, Gregorich EG (2008) Soil sampling and methods of analysis. 2nd ed. CRC Press, Taylor \& Francis Group.

16. Cavard X, Bergeron Y, Paré D, Nilsson M-C, Wardle DA (2019) Disentangling Effects of Time Since Fire, Overstory Composition and Organic Layer Thickness on Nutrient Availability in Canadian Boreal Forest. Ecosystems 22: 33. doi: 10.1007/s10021-018-0251-3.

17. Certini G (2005) Effects of fire on properties of forest soils: a review. Oecologia 143: 1-10.

18. Creamer CA, Jones DL, Baldock JA, Farrell M (2014) Stoichiometric controls upon low molecular weight carbon decomposition. Soil Biology and Biochemistry 79: 50-56. doi: 10.1016/j.soilbio.2014.08.019. 
19. De Long JR, Dorrepaal E, Kardol P, Nilsson M-C, Teuber LM, Wardle DA (2016) Understory plant functional groups and litter species identity are stronger drivers of litter decomposition than warming along a boreal forest post-fire successional gradient. Soil Biology \& Biochemistry 98: 159-170. doi: 10.1016/j.soilbio.2016.04.009.

20. DeLuca TH, Zackrisson O, Gundale MJ, Nilsson M-C (2008) Ecosystem feedbacks and nitrogen fixation in boreal forests. Science 320 .

21. Dijkstra FA, Adams MA (2015) Fire Eases Imbalances of Nitrogen and Phosphorus in Woody Plants. Ecosystems 18. doi: 10.1007/s10021-015-9861-1.

22. Durán J, Rodríguez A, Fernández-Palacios JM, Gallardo A (2008) Changes in soil N and P availability in a Pinus canariensis fire chronosequence. Forest Ecol Manag 256: 384-387. doi:

10.1016/j.foreco.2008.04.033.

23. Fan H, Wu J, Liu W, Yuan Y, Hu L, Cai Q (2015) Linkages of plant and soil C:N:P stoichiometry and their relationships to forest growth in subtropical plantations. Plant and soil 392: 127-138. doi: 10.1007/s11104-015-2444-2).

24. Fernández C, Vega, J.A., (2016) Effects of mulching and post-fire salvage logging on soil erosion and vegetative regrowth in NW Spain. Forest Ecol Manag 375: 46-54.

25. Gill RA, Jackson RB (2000) Global patterns of root turnover for terrestrial ecosystems. New Phytol 147: 13-31.

26. Harden JW, Mack M, Veldhuis H, Gower ST (2003) Fire dynamics and implications for nitrogen cycling in boreal forests. Journal of Geophysical Research 108: 8223-8230. doi: $10.1029 / 2001 j \mathrm{j} 000494$.

27. Huang L-M, Jia X-X, Zhang G-L, Shao M-A (2017) Soil organic phosphorus transformation during ecosystem development: A review. Plant and Soil 417: 17-42. doi: 10.1007/s11104-017-3240-y.

28. Hume A, Chen HYH, Taylor AR, Kayahara GJ, Man R (2016) Soil C:N:P dynamics during secondary succession following fire in the boreal forest of central Canada. Forest Ecol Manag 369: 1-9. doi: 10.1016/j.foreco.2016.03.033.

29. Johnson D, Murphy JD, Walker RF, Glass DW, Miller WW (2007) Wildfire effects on forest carbon and nutrient budgets. Ecol Eng 31: 183-192. doi: 10.1016/j.ecoleng.2007.03.003.

30. Kane ES, Hockaday WC, Turetsky MR, Masiello CA, Valentine DW, Finney BP, Baldock JA (2010) Topographic controls on black carbon accumulation in Alaskan black spruce forest soils: implications for organic matter dynamics. Biogeochemistry 100: 39-56. doi: 10.1007/s10533-0099403-z.

31. Kishchuk BE, Morris DM, Lorente M, Keddy T, Sidders D, Quideau S, Thiffault E, Kwiaton M, Maynard D (2016) Disturbance intensity and dominant cover type influence rate of boreal soil carbon change: A Canadian multi-regional analysis. Forest Ecol Manag 381: 48-62. doi: 10.1016/j.foreco.2016.09.002.

32. Kong JJ, Yang J, Bai E (2018) Long-term effects of wildfire on available soil nutrient composition and stoichiometry in a Chinese boreal forest. The Science of the total environment 642: 1353-1361. 
doi: 10.1016/j.scitotenv.2018.06.154.

33. Kong JJ, Yang J, Chu H, Xiang X (2015) Effects of wildfire and topography on soil nitrogen availability in a boreal larch forest of northeastern China. Int J Wildland Fire 24: 433-442. doi: 10.1071/wf13218.

34. Kong JJ, Yang J, Liu B, Qi L (2019) Wildfire Alters Spatial Patterns of Available Soil Nitrogen and Understory Environments in a Valley Boreal Larch Forest. Forests 10: 95. doi: 10.3390/f10020095.

35. Kyaschenko J, Ovaskainen O, Ekblad A, Hagenbo A, Karltun E, Clemmensen KE, Lindahl BD (2019) Soil fertility in boreal forest relates to root-driven nitrogen retention and carbon sequestration in the mor layer. The New phytologist 221: 1492-1502. doi: 10.1111/nph.15454.

36. Lagerström A, Esberg C, Wardle DA, Giesler R (2009) Soil phosphorus and microbial response to a long-term wildfire chronosequence in northern Sweden. Biogeochemistry 95: 199-213. doi: 10.1007/s10533-009-9331-y.

37. Liu Z, Yang J (2014) Quantifying ecological drivers of ecosystem productivity of the earlysuccessional borealLarix gmeliniiforest. Ecosphere 5: 1-16. doi: 10.1890/es13-00372.1.

38. Luo G, Chao X, Jiang Q, Xiao Y, Zhang F, Guo S, Shen Q, Ling N (2020) Soil Carbon, Nitrogen, and Phosphorus Cycling Microbial Populations and Their Resistance to Global Change Depend on Soil C:N:P Stoichiometry. msystems 5: e00162-00120.

39. Matamala R, Gonzàlez-Meler MA, Jastrow JD, Norby RJ, Schlesinge WH (2003) Impacts of fine root turnover on forest NPP and soil C sequestration potential. Science 302: 1385-1387.

40. Nave LE, Vance ED, Swanston CW, Curtis PS (2011) Fire effects on temperate forest soil C and N storage. Ecol Appl 21: 1189-1201.

41. Pereira P, Rein G, Martin D (2016) Past and present post-fire environments. Sci Total Environ 573: 1275-1277.

42. Ren C, Zhao F, Kang D, Yang G, Han X, Tong X, Feng Y, Ren G (2016) Linkages of C:N:P stoichiometry and bacterial community in soil following afforestation of former farmland. Forest Ecol Manag 376: 59-66. doi: 10.1016/j.foreco.2016.06.004.

43. Romme WH, Tinker DB, Stakes GK, Turner MG (2009) Does inorganic nitrogen limit plant growth 3-5 years after fire in a Wyoming, USA, lodgepole pine forest? Forest Ecol Manag 257: 829-835. doi: 10.1016/j.foreco.2008.10.013.

44. Santín C, Doerr SH, Merino A, Bryant R, Loader NJ (2016) Forest floor chemical transformations in a boreal forest fire and their correlations with temperature and heating duration. Geoderma 264: 71-80. doi: 10.1016/j.geoderma.2015.09.021.

45. Schafer JL, Mack MC (2014) Foliar Nutrient Concentrations and Ratios of Scrubby Flatwoods Species Change with Time After Fire. Castanea 79: 237-245. doi: 10.2179/14-013.

46. Schaller J, Tischer A, Struyf E, Bremer M, Belmonte DU, Potthast K (2015) Fire enhances phosphorus availability in topsoils depending on binding properties. Ecology 96: 1598-1606. 
47. Shen F, Wu J, Fan H, Liu W, Guo X, Duan H, Hu L, Lei X, Wei X (2018) Soil N/P and C/P ratio regulate the responses of soil microbial community composition and enzyme activities in a long-term nitrogen loaded Chinese fir forest. Plant and Soil 436: 91-107. doi: 10.1007/s11104-018-03912-y.

48. Shuman JK, Foster AC, Shugart HH, Hoffman-Hall A, Krylov A, Loboda T, Ershov D, Sochilova E (2017) Fire disturbance and climate change: implications for Russian forests. Environ Res Lett 12: 035003. doi: 10.1088/1748-9326/aa5eed.

49. Sistla SA, Schimel JP (2012) Stoichiometric flexibility as a regulator of carbon and nutrient cycling in terrestrial ecosystems under change. The New phytologist 196: 68-78. doi: 10.1111/j.14698137.2012.04234.x.

50. Smithwick EAH, Turner MG, Mack MC, Chapin FS (2005) Postfire soil N cycling in northern conifer forests affected by severe, stand-replacing wildfires. Ecosystems 8: 163-181. doi: 10.1007/s10021004-0097-8.

51. Sophie Z-B, Katharina MK, Maria M, Josep P, Andreas R, Jordi S, Wolfgang W (2015) The application of ecological stoichiometry to plant-microbial-soil organic matter transformations. Ecol Monogr 85: 133-155.

52. Stocks BJ, Fosberg MA, Lynham TJ, Mearns L, Wotton BM, Yang Q, Jin J-Z, Lawrence K, Hartley GR, Mason JA, McKENNEY DW (1998) Climate change and forest fire potential in Russian and Canadian boreal forests. Climatic Change 38: 1-13.

53. Toberman H, Chen C, Lewis T, Elser JJ (2014) High-frequency fire alters C : N : P stoichiometry in forest litter. Glob Chang Biol 20: 2321-2331. doi: 10.1111/gcb.12432.

54. Turner MG, Smithwick EA, Metzger KL, Tinker DB, Romme WH (2007) Inorganic nitrogen availability after severe stand-replacing fire in the Greater Yellowstone ecosystem. Proceedings of the National Academy of Sciences 104: 4782-4789. doi: 10.1073/pnas.0700180104.

55. Vogt KA, Vogt DJ, Palmiotto PA, Boon P, O'Hara J, Asbjornsen H (1996) Review of root dynamics in forest ecosystems grouped by climate, climatic forest type and species. Plant and Soil 187: 159-219.

56. Walker J, Thompson C, Jehne W (1983) Soil weathering stage, vegetation succession and canopy dieback. Pacific Science 37: 471-481.

57. Walkley A, Black IA (1934) An examination of the degtjareff method for determining soil organic matter, and a proposed modification of the chromic acid titration method. Soil Science 37: 29-38.

58. Wei X, Zhu Z, Liu Y, Luo Y, Deng Y, Xu X, Liu S, Richter A, Shibistova O, Guggenberger G, Wu J, Ge T (2020) C:N:P stoichiometry regulates soil organic carbon mineralization and concomitant shifts in microbial community composition in paddy soil. Biology and Fertility of Soils 56: 1093-1107. doi: 10.1007/s00374-020-01468-7.

59. Wirth C, Schulze E-D, Lühker B, Grigoriev S, Siry M, Hardes G, Ziegler W, Backor M, Bauer G, Vygodskaya NN (2002) Fire and site type effects on the long-term carbon and nitrogen balance in pristine Siberian Scots pine forests. Plant and Soil 242: 41-63.

60. Xiang X, Gibbons SM, Yang J, Kong J, Sun R, Chu H (2015) Arbuscular mycorrhizal fungal communities show low resistance and high resilience to wildfire disturbance. Plant and Soil 397: 
347-356. doi: 10.1007/s11104-015-2633-z.

61. Xiang X, Shi Y, Yang J, Kong J, Lin X, Zhang H, Zeng J, Chu H (2014) Rapid recovery of soil bacterial communities after wildfire in a Chinese boreal forest. Sci Rep 4: 3829. doi: 10.1038/srep03829.

62. Xu HC (1998) Da Hinggan Ling mountains forests in China. Science Press, Beijing (in Chinese).

63. Yuan ZY, Chen H (2010) Fine Root Biomass, Production, Turnover Rates, and Nutrient Contents in Boreal Forest Ecosystems in Relation to Species, Climate, Fertility, and Stand Age: Literature Review and Meta-Analyses. Crit Rev Plant Sci 29: 204-221. doi: 10.1080/07352689.2010.483579.

64. Yuan ZY, Chen HYH (2013) Effects of Disturbance on Fine Root Dynamics in the Boreal Forests of Northern Ontario, Canada. Ecosystems 16: 467-477. doi: 10.1007/s10021-012-9623-2.

65. Zhang W, Liu W, Xu M, Deng J, Han X, Yang G, Feng Y, Ren G (2019) Response of forest growth to C:N:P stoichiometry in plants and soils during Robinia pseudoacacia afforestation on the Loess Plateau, China. Geoderma 337: 280-289. doi: 10.1016/j.geoderma.2018.09.042.

\section{Figures}
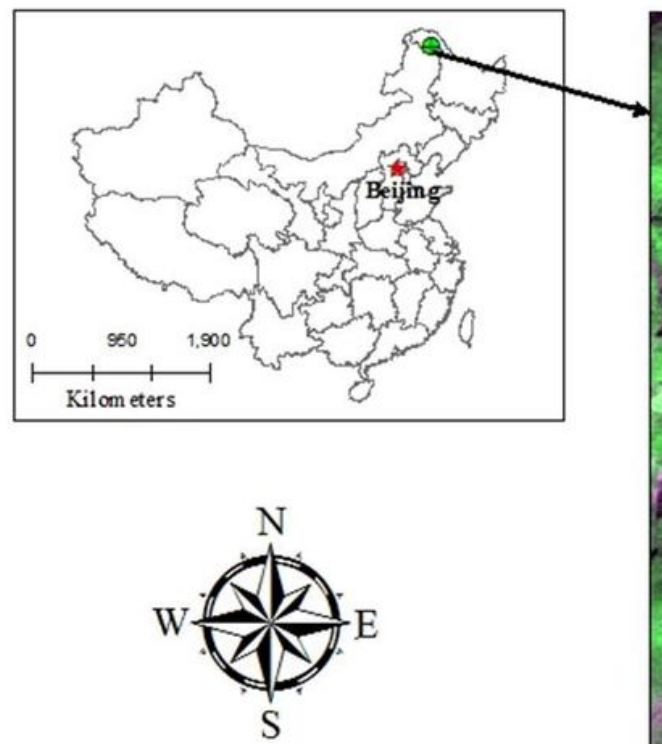

\section{Legend}

$\square \quad$ Sampling site

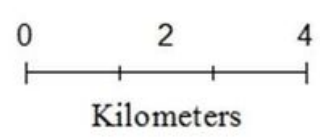

Kilometers
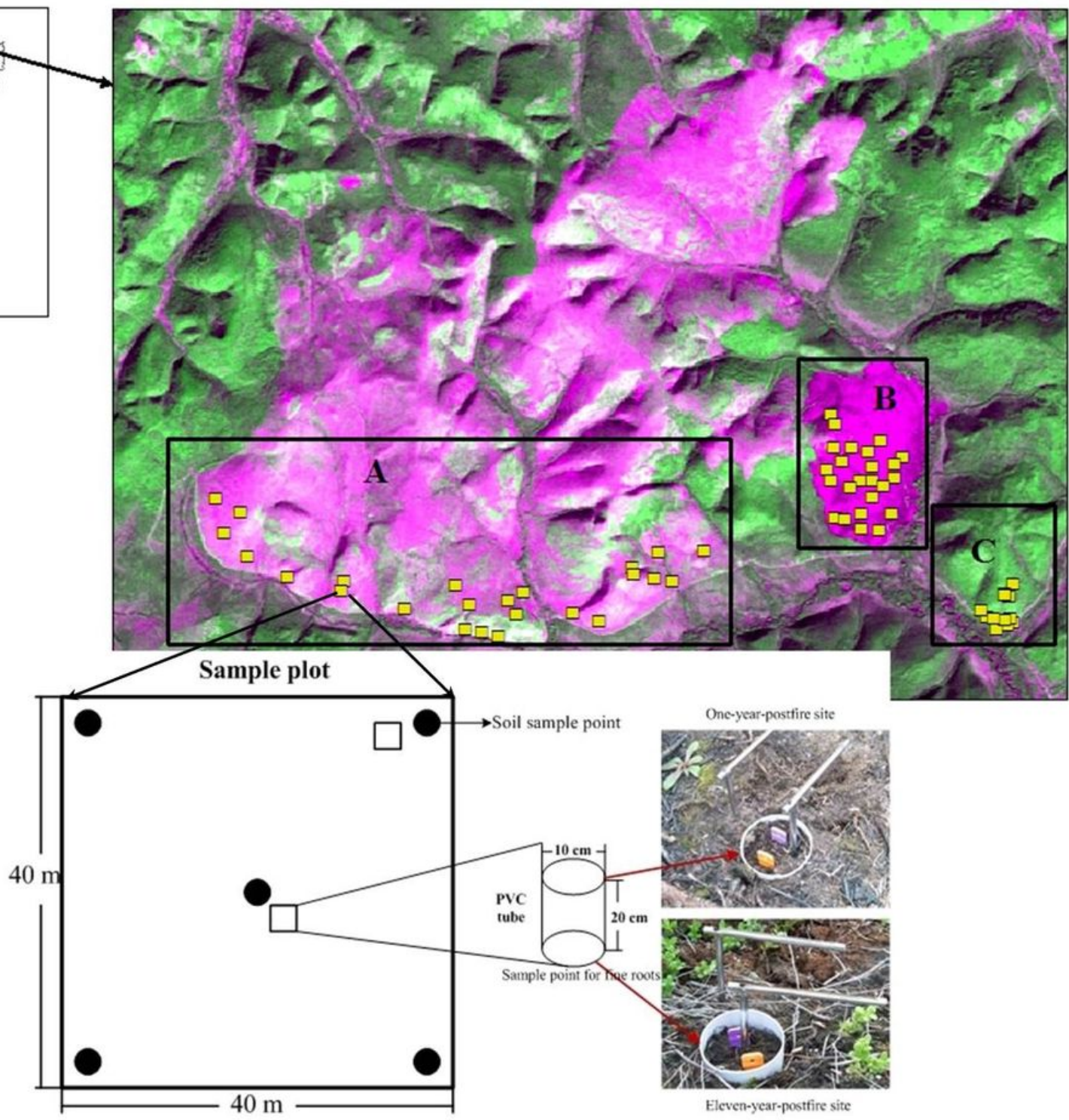
Figure 1

Study area and sampling plots (little yellow square) of Great Xing'an Mountains in northeastern China and the sampling process. Polygon A represents the 11-year-post-fire site appearing bright pink color due to the vegetation recovery and black carbon erosion, polygon B represents the1-year-post-fire site appearing fresh red due to high black carbon coverage and high vegetation mortality, polygon $\mathrm{C}$ represents the unburned control site which is green due to vegetation cover. The false color Landsat TM images (NASA Landsat Program, 2010, Landsat TM scene LT51210242010254IKR02, L1T, USGS, Sioux Falls, 09/11/2010) were obtained from USGS GLOVIS (https://glovis.usgs.gov/).

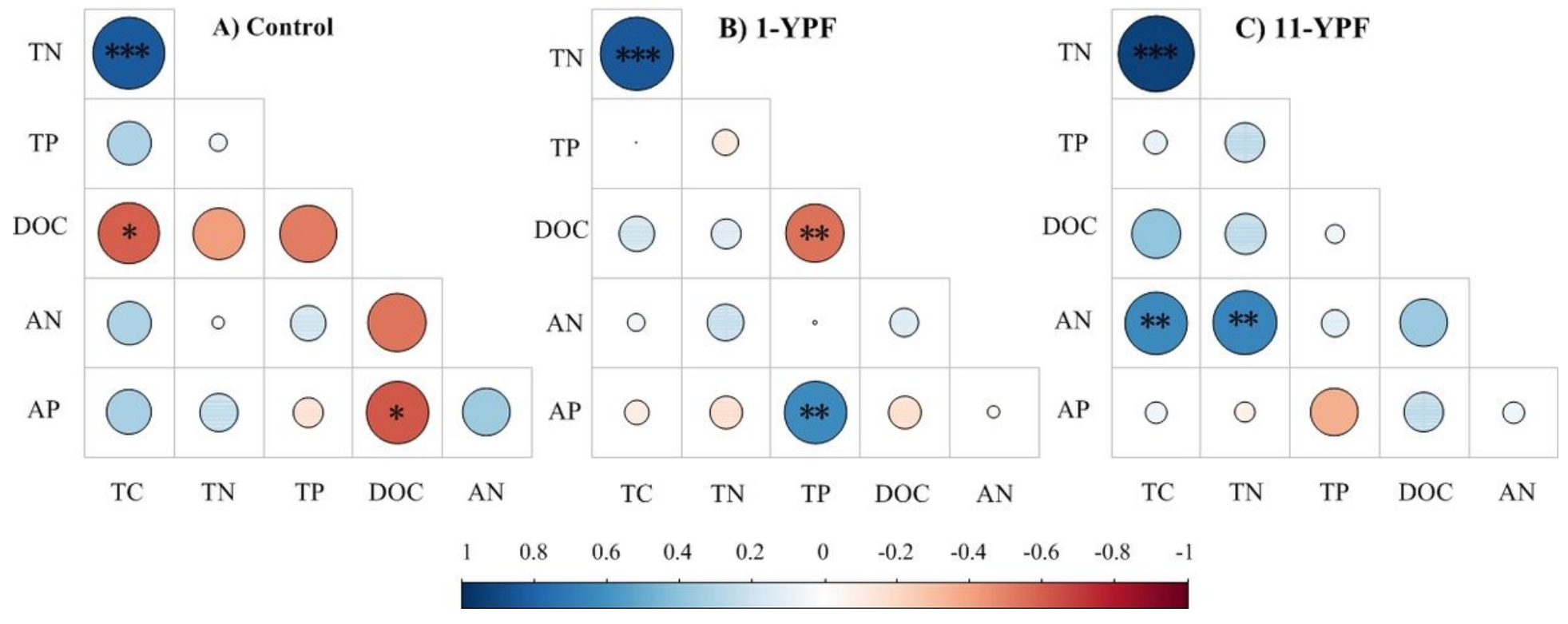

\section{Figure 2}

Spearman's rank correlation coefficients ( $r$ ) between total and available soil $\mathrm{C}, \mathrm{N}$ and $\mathrm{P}$ concentrations at the control ( $n=12$ plots), 1-year-post-fire (1-YPF, $n=24$ plots), and 11-year-post-fire (11-YPF, $n=24$ plots) sites. ${ }^{*} p<0.05 . * \star p<0.01$. 
Control
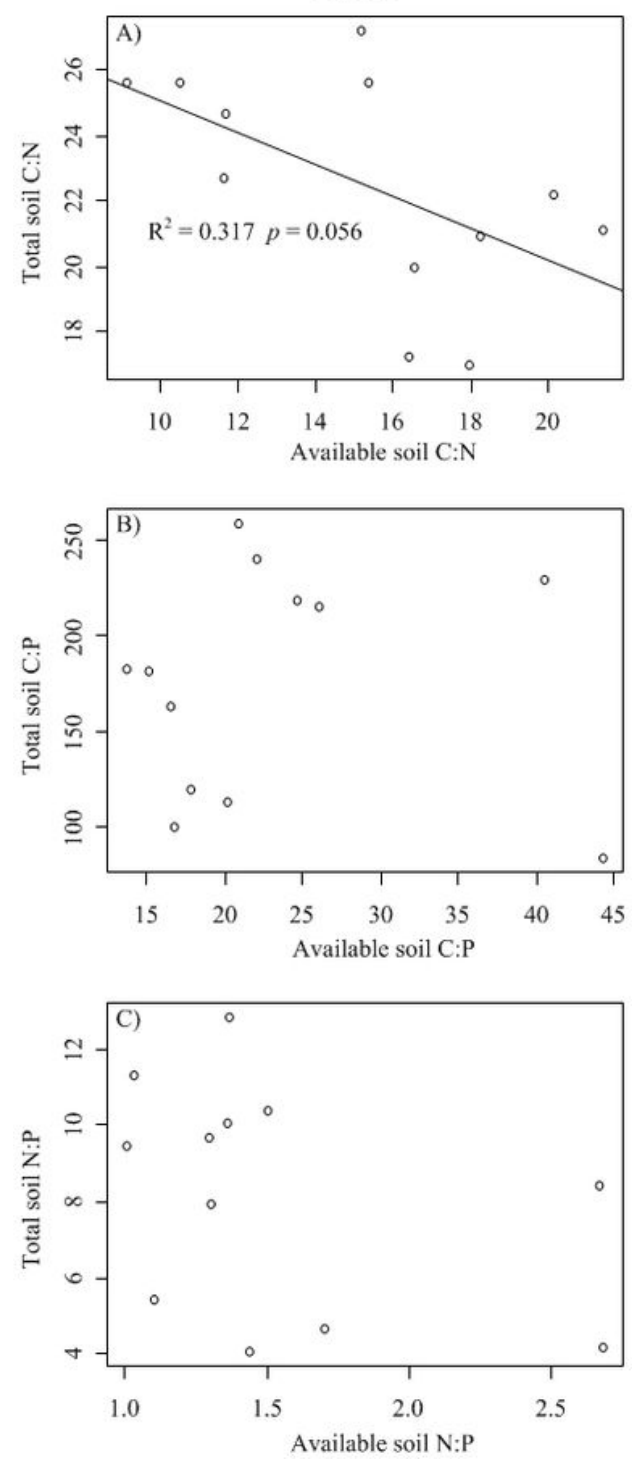

1-year-post-fire
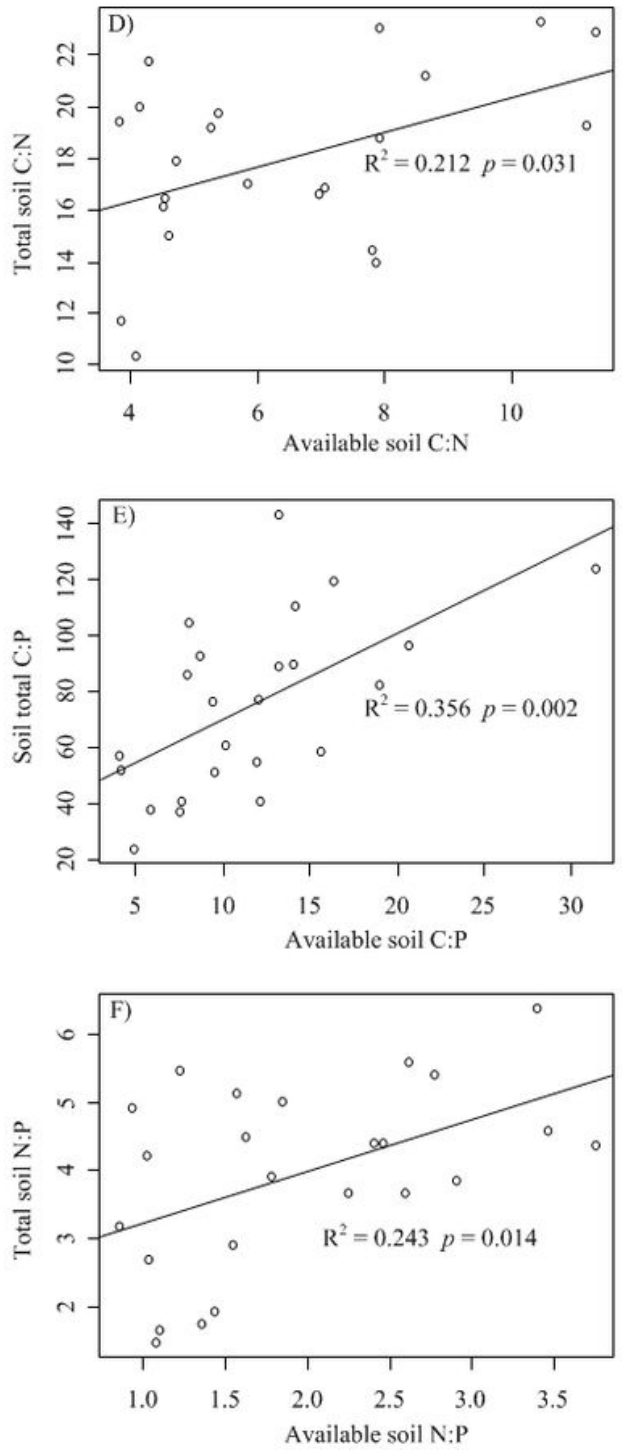

11-year-post-fire
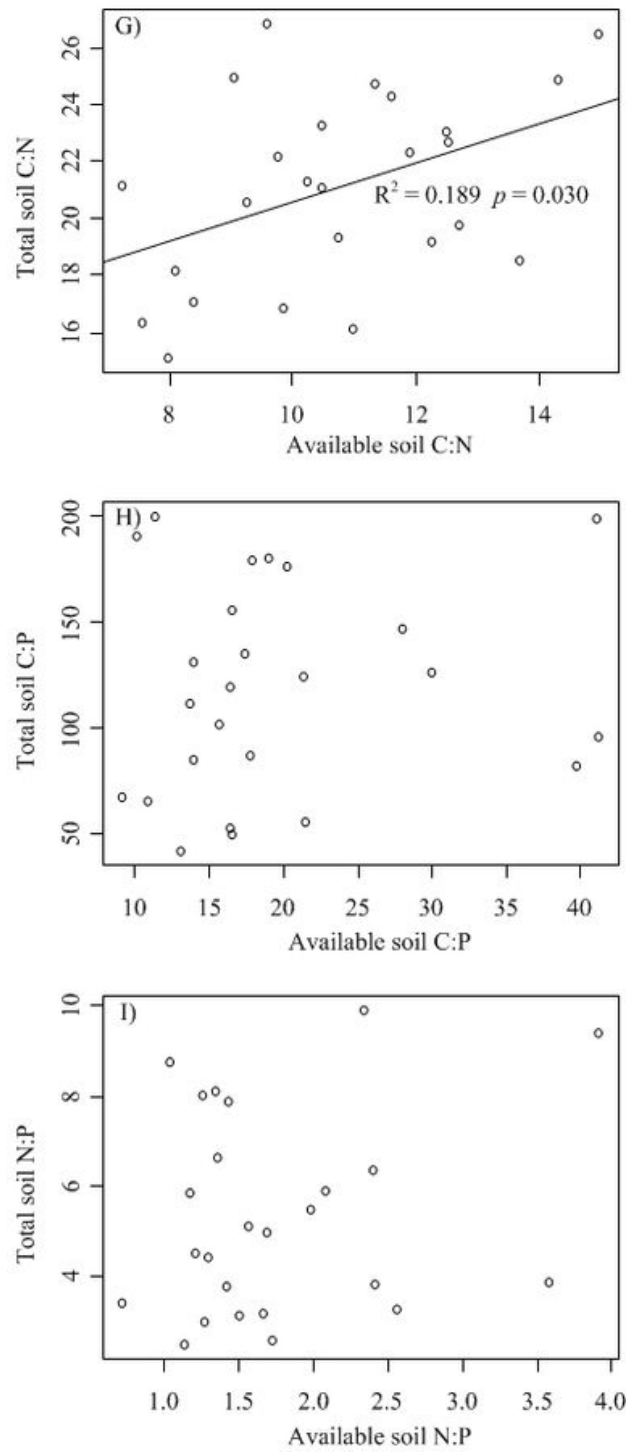

Figure 3

Linear regression relationships between total and available soil C:N, C:P and N:P each in the control $(\mathrm{n}=$ 12 plots), 1-year-post-fire ( $\mathrm{n}=24$ plots), and 11-year-post-fire ( $\mathrm{n}=24$ plots) sites. 

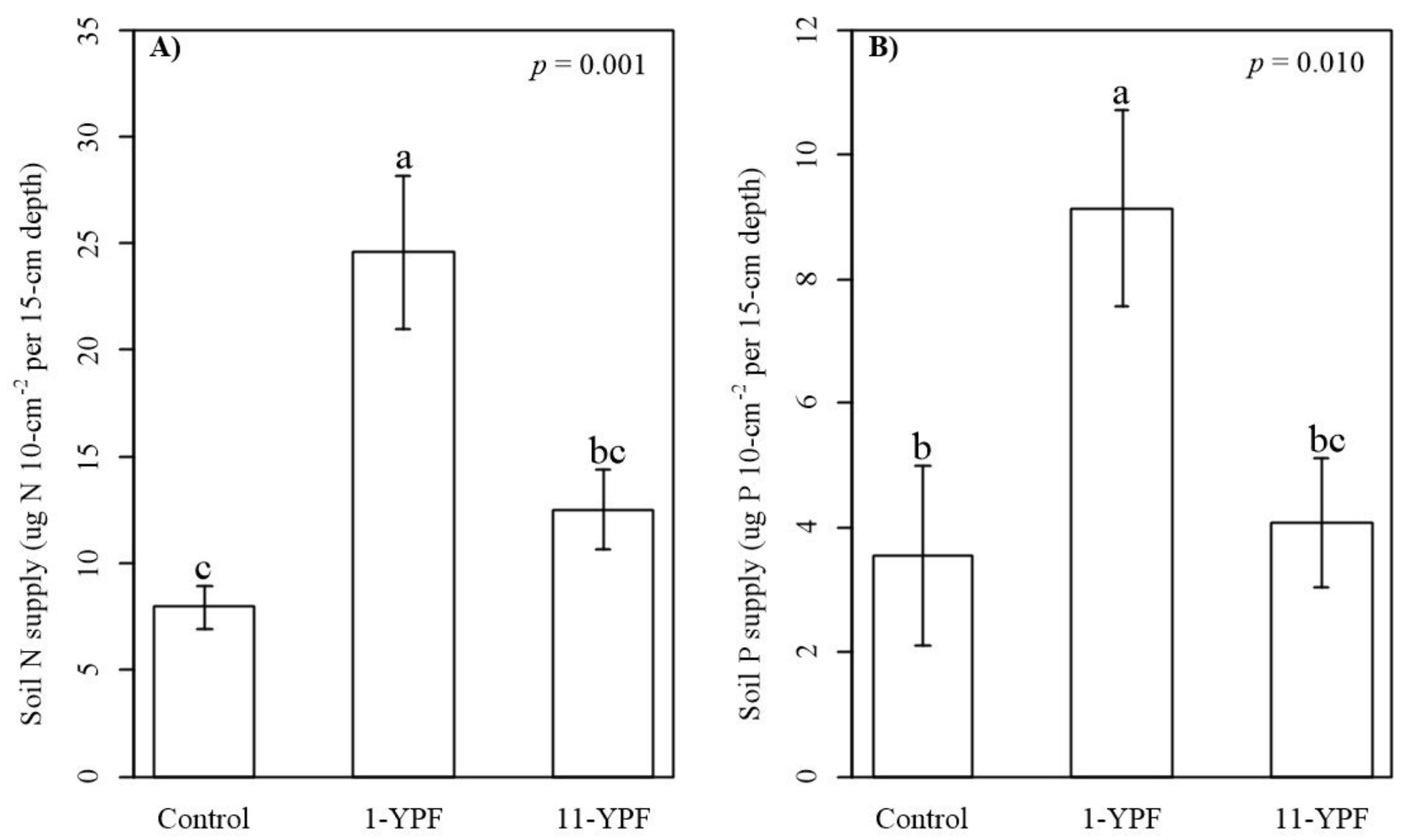

Figure 4

Soil $\mathrm{N}$ and $\mathrm{P}$ supply at the control ( $\mathrm{n}=12$ plots), 1-year-post-fire (1-YPF, $\mathrm{n}=24$ plots), and 11-year-post-fire (11-YPF, $n=24$ plots) sites. 


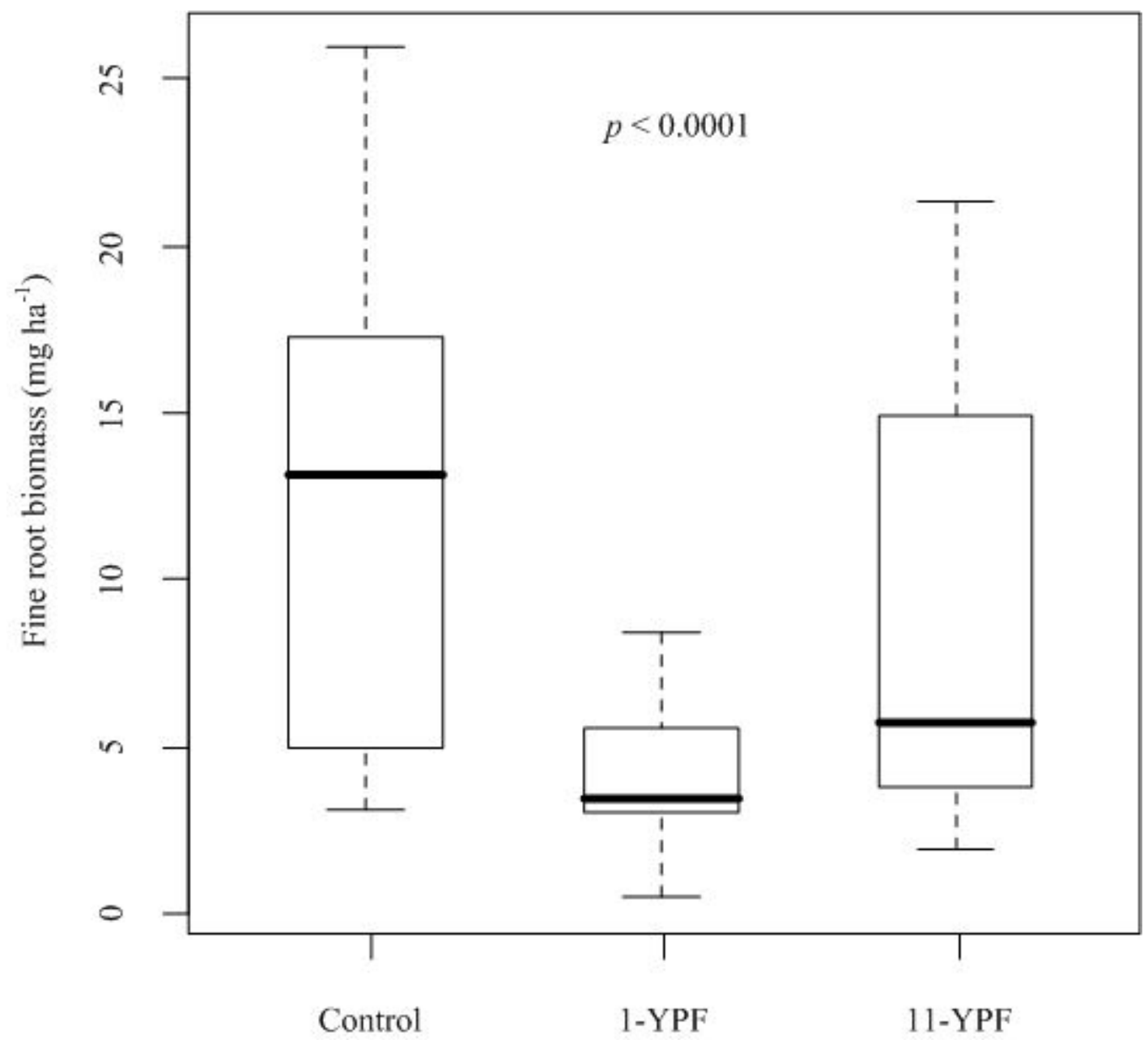

Figure 5

Fine root biomass at the control ( $n=12$ plots), 1-year-post-fire $(n=24$ plots $)$, and 11-year-post-fire $(n=24$ plots) sites.
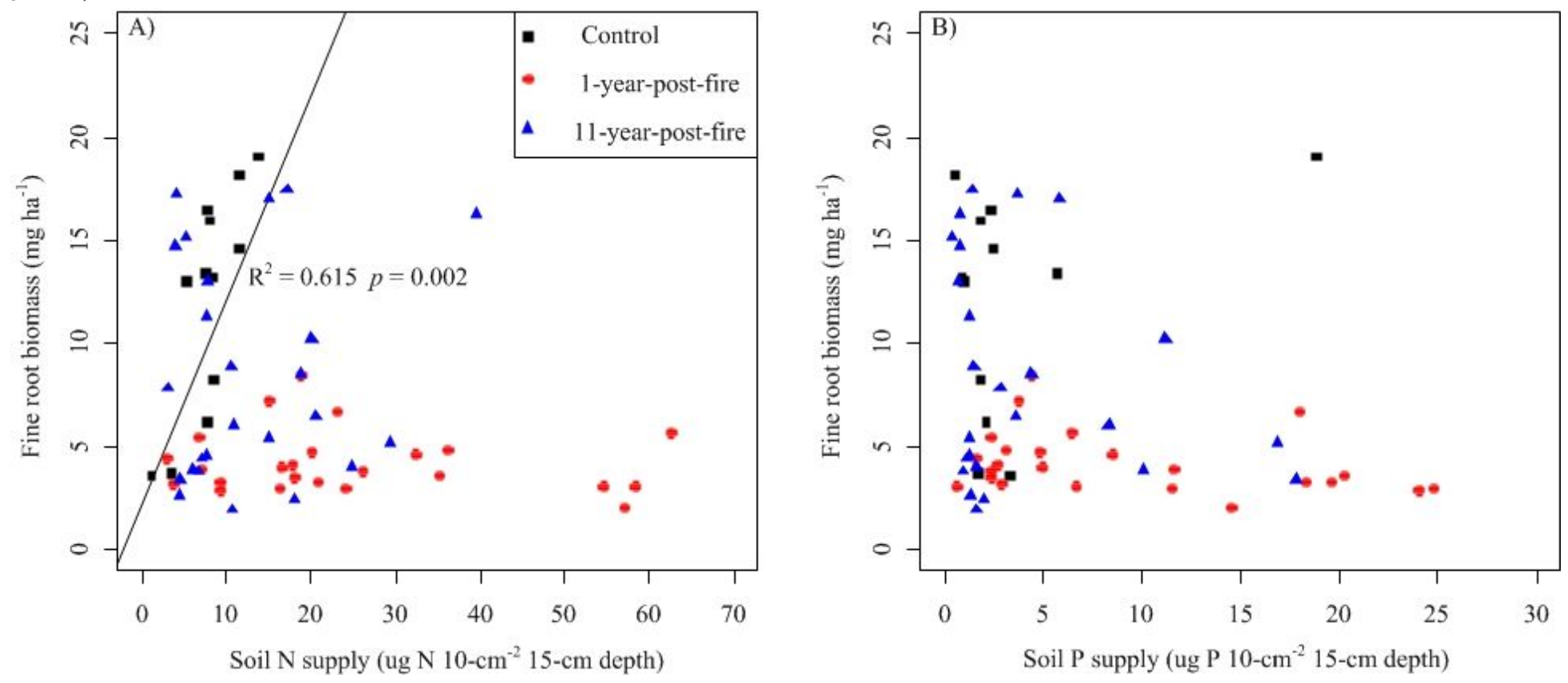

Figure 6 
Linear regression relationships between fine root biomass and soil nutrient supply at the control $(n=12$ plots), 1-year-post-fire ( $\mathrm{n}=24$ plots), and 11-year-post-fire ( $\mathrm{n}=24$ plots $)$ sites.
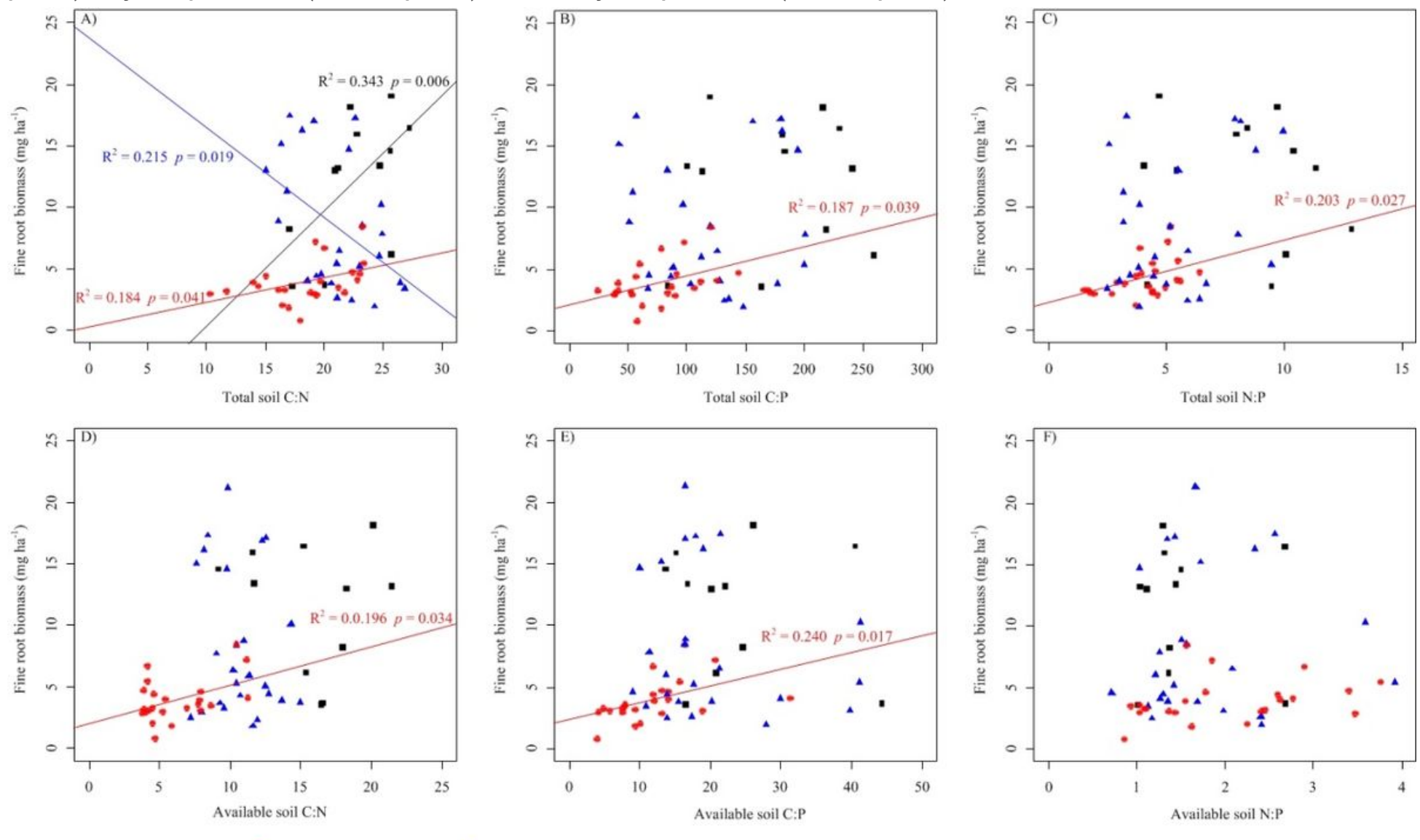

- Control

- 1-year-post-fire

4 11-year-post-fire

Figure 7

Linear regression relationships between fine root biomass and total and available soil C:N:P stoichiometry at the control ( $n=12$ plots), 1-year-post-fire (1-YPF, $n=24$ plots), and 11-year-post-fire (11YPF, $n=24$ plots) sites. 